\title{
Single Beat QT Interval
}

National Cancer Institute

\section{Source}

National Cancer Institute. Single Beat QT Interval. NCI Thesaurus. Code C117788.

An electrocardiog raphic interval measured from the onset of the QRS complex to the offset of the T wave of a single beat utilizing one or more leads. (CDISC) 